\title{
Evaluating Flipped Versus Face-to-face Classrooms in Middle School on Science Achievement and Student Perceptions
}

\author{
Erin Stratton \\ Tennessee Tech University, TN, USA \\ ORCID: 0000-0001-7520-6992 \\ George Chitiyo \\ Tennessee Tech University, TN, USA \\ ORCID: 0000-0002-0264-6513 \\ Allen M. Mathende \\ Tennessee Tech University, TN, USA \\ ORCID: 0000-0002-7261-0065 \\ Krista M. Davis \\ Tennessee Tech University, TN, USA \\ ORCID: 0000-0003-2198-4822
}

\begin{abstract}
The purpose of this study was to compare how face-to-face instruction and flipped learning differed in terms of student achievement in seventh grade science classes, as well as to assess how students who were in the flipped classroom felt about their experiences. A total of 81 students received face-to-face instruction, and 73 received flipped instruction. All students completed pre- and post-assessments. Additionally, students in the flipped classroom completed a survey to assess perceptions of their experiences with the flipped model. Analysis of variance results showed no differences in performance between the two groups of students. There were also no interactions between instructional method with both gender and ability. The student survey data showed that the majority of students enjoyed the flipped model. Large percentages of students reported increased engagement and motivation under the flipped model. In conclusion, we found that flipped instruction was as effective as face-to-face instruction.
\end{abstract}

Keywords: flipped classroom, seventh grade, perceptions, face-to-face instruction

\section{INTRODUCTION}

Education in the United States has changed drastically in the last decade. There is an increased prevalence of technology use in the classroom, allowing teachers and students to do things they never dreamt of before. Given that today's students are digital natives, Groff (2013) reports that many educators are finding traditional learning environments needing to be enhanced to be more engaging to students. Traditional learning approaches have been defined as teachercentered instructional delivery methods where the teacher gives the students information, and the students are recipients of the information (Jony, 2016). Lenhart (2015) found that $87 \%$ of teens reported having computer access at home. Additionally, $73 \%$ had access to a smartphone. 
If kids are already using this technology, it makes sense for educators to leverage this to the students' benefit. Jony (2016) found that traditional learning approaches made students passive participants in the learning process, and thus, called for more student-centered approaches in which students take responsibility of their learning by "choos[ing] how they will learn, and how they will assess their own learning" (p. 172).

Educators--both in K-12 and post-secondary-are looking for new ways to use the technology that is now available to them. Many argue that traditional methods do not reach today's learners (Agnello, Pikas, Agnello, \& Pikas, 2011). One method of providing instruction that has become more common in recent years is the concept of the flipped classroom. There are many variations of flipped learning/instruction; one of the more common models is blended learning. As described by Garrison and Kanuka (2004), blended learning is the "integration of classroom faceto-face learning experiences with online learning experiences" (p. 96). Flipping the classroom literally flips the traditional model of education on its head, moving content transmission outside of the classroom and moving practice activities that would traditionally be done at home, into the classroom, where the "expert," or teacher, is there to provide additional support (Bergmann \& Sams, 2015). A carefully implemented flipped classroom has the potential to encourage students to be active participants in their own learning rather than merely being passive consumers of the information (Hunley, 2016).

Noonoo (2017) discovered that $16 \%$ of teachers in the United States flipped some part of their instruction, $35 \%$ of teachers wanted to learn more about how to flip their classroom, and that-at the time of publication-less than $10 \%$ of the literature comprised studies of $\mathrm{K}-12$ education. Another study conducted by Project Tomorrow (2013) showed that $61 \%$ of the surveyed students believed that the flipped classroom would improve their performance in the classroom.

\section{The Practice of Flipping the Classroom}

The flipped classroom is a relatively new instructional method. Two Colorado chemistry teachers, Bergmann and Sams, helped grow this pedagogical approach by developing videos for their absent students (Arnold-Garza, 2014). Within the last decade, the flipped classroom has evolved to become a popular teaching method (Bormann, 2014; Jony, 2016; Strayer, 2012). However, it is important for teachers to understand basic pedagogy before attempting a new instructional strategy, such as how the model will impact the students' ability to think critically, collaborate in their learning, and interact towards the success of their learning (Strohmyer, 2016). Flipped learning involves moving lectures outside of the walls of the classroom so that inside the classroom student-teacher interaction is increased, more time for active learning is created, the time students and teachers spend together is used more effectively (Bergmann \& Sams, 2012; Kirch, 2016; Schmidt \& Ralph, 2016), student engagement is improved (Clark, 2015; Gross, Hoffman, Marinari, DeSimone, \& Burke, 2015; Newman, Kim, Lee, Brown, \& Huston, 2016 ; Ryan \& Reid, 2015), and a platform for content application between the teacher and the students is created (Graham, Woodfield, \& Harrison, 2013; Grant, 2013). Class activities are used to help students relate the learned content to real-world situations and explain any concepts they may have missed during their reading. Compared to traditional techniques like memorization or teacher-led lecturing, the use of the flipped classroom is believed to support students' comprehension of concepts more (Bhagat, Chang, \& Chang, 2016; Bormann, 2014; Kim, Jung, de Siqueira, \& Huber, 2016). The reduced focus on student memorization creates opportunities for students to gain life-long skills they can use for other subjects and real-life situations (Lee \& Kim, 2018). 
When lectures are moved outside the walls of a classroom, students need monitoring and guidance in order for the benefits of creating more classroom time to be realized (Clark, 2015; Desantis, Van Curen, \& Putsch, 2015; Gross et al., 2015; Newman et al., 2016; Ryan \& Reid, 2015). Students can be assigned videos to watch before class, for which they are required to take notes, write a summary of the learned concepts, and answer questions. The teacher either creates the videos or requests students to watch available online videos created by other reputable educators (Tawfik \& Lilly, 2015; Wenzler, 2017). Methods such as the WatchSummarize-Question (WSQ) have been developed to help students to glean as much knowledge as possible from assigned material (Kirch, 2016). Summarizing has proven to be an effective strategy to improve student recall (King, Biggs, \& Lipsky, 1984). This, along with questioning, helps ensure that students are interacting with the videos, not just passively taking them in (Cavey \& Mahavier, 2010). Such methods incentivize students to watch the videos at home "just like they need to be motivated to read their textbooks and do their homework" (El Miedany, \& El Miny, 2018, p. 299). Students then have time to discuss content they learned from the video in the classroom with their teacher by participating in activities that relate to the video material (Bhagat et al., 2016).

Proponents of the flipped classroom postulate that the benefits of flipped learning include higher levels of achievement, improved engagement (Alvarez, 2012; Clark, 2015; Desantis et al., 2015; Newman et al., 2016), and greater connections between teachers and the digital native generation. Furthermore, other research has shown that flipped classroom teachers were able to provide timely feedback to the students and model learning concepts around complex topics identified by students (Smallhorn, 2017). Newman et al. (2016) found this to hold across age, gender, and students at different educational levels.

Research on flipped learning has had mixed outcomes on the benefits of flipping a class when analyzed by gender. Chen, Young, and Hsiao (2016) and González-Gómez, Guardiola, Rodríguez, and Alonso (2012) found that females benefited more than males from the flipped learning environment, despite typically showing less interest and confidence in the subject matter. Females fared better with more communication, clear expectations, and active participation. The effects of flipping on other classroom activities varied between genders, depending on the activity being measured (Lax, Morris, \& Kolber, 2016). The learning outcomes were not statistically significantly different between males and females.

\section{Student Perceptions}

It is important to evaluate students' perceptions of their learning in a flipped classroom to determine whether they think they are benefiting. Perceptions have been generally found to be positive when it comes to flipped classrooms. Flipping the classroom supposedly gives students ownership of their own learning, improving their perceptions, and positive perceptions have the potential to improve grades (Jamaludin \& Osman, 2014). Strohmyer (2016) conducted a study to understand the lived experiences of students in a math class who had experienced a flipped learning model. He found that students' perception towards engagement and interaction with others improved with the use of the flipped classroom. Further findings from the study showed that there were increases in in-depth learning by the students.

Many benefits can accrue from letting students be the drivers of their own education. Students have expressed that flipped learning has helped them understand academic content better, partly because of self-pacing the instruction (Smallhorn, 2017; Wilson, 2013). Strohmyer (2016), stated that students' perceptions were positive in relation to their ability to self-regulate their learning. Likewise, Borman (2014) found that students' perceptions changed when they were 
given ownership of their learning process. Students improve their social and academic interactions when provided with an active learning environment, which fosters deep and meaningful learning (Lee \& Kim, 2018). Furthermore, a study by Hunley (2016) supported this finding as students highlighted that they were able to collaborate with other students and communicate with their teacher more. The students were able to work in teams and share knowledge outside the bounds of the school environment.

Results of a survey study conducted by Lee and Kim (2018) found that students' perception of their performance in class improved after receiving instruction in a flipped classroom. Similarly, Hunley's (2016) study revealed that students believed the flipped classroom afforded them flexibility in their learning and the ability to catch up with course material they would have missed. Despite positive perceptions of the flipped classroom, one drawback mentioned by students was that the model heavily relied on the internet, which, when it was down, prevented their ability to work on their school activities (Hunley, 2016).

\section{The Research Problem}

The purpose of this study was to compare how face-to-face instruction and flipped learning differed in terms of student achievement in six seventh grade science classes, as well as to gauge how students who were in the flipped classroom felt about their experiences. Three of the classes received face-to-face instruction, and the remaining three classes received flipped instruction. All students completed multiple choice pre- and post-assessments. Additionally, students who experienced the flipped classroom completed a survey at the end to provide perceptions of their experiences with the flipped model.

The school studied had Chromebooks available for all students, allowing each student to have access to a device in every classroom in which they participated. The school system encouraged the use of online learning and many advanced classes were either offered online or used the flipped classroom approach. Regardless of how many times one has taught a concept, it is not easy to accurately predict what the next group of students will need most from a lecture or what questions they will ask.

\section{METHODS}

\section{Sample}

After approval of the Board of Education, informed consent was received from the parents of all participants who were seventh-grade students attending a public, Title I middle school in a city in the southeastern United States. Groups were composed of intact classes in the spring semester of the 2017/2018 school year. The classes that received face-to-face instruction had a total of 81 students: 52 boys and 29 girls. The classes that received the flipped treatment had 73 students: 27 boys and 35 girls. Both groups included students of all academic ability levels, though the sample excluded students with Individualized Education Plans (IEPs). The distribution of students by instructional method, gender, and ability is shown in Table 1. 
Table 1. Distribution of Students by Instructional Method, Ability, and Gender

\begin{tabular}{cccc}
\hline \multicolumn{1}{l}{ Face-to-face classroom } & Flipped classroom & Total \\
\hline \multicolumn{1}{l}{ Gender } & & & \\
\hline Female & $35.8 \%(n=29)$ & $56.5 \%(n=35)$ & $44.8 \%(n=64)$ \\
\hline Male & $64.2 \%(n=52)$ & $43.5 \%(n=27)$ & $55.2 \%(n=79)$ \\
\hline Aptitude & & & \\
\hline Low aptitude & $38.3 \%(n=31)$ & $30.6 \%(n=19)$ & $35.0 \%(n=50)$ \\
\hline Middle aptitude & $35.8 \%(n=29)$ & $27.4 \%(n=17)$ & $32.2 \%(n=46)$ \\
\hline High aptitude & $25.9 \%(n=21)$ & $41.9 \%(n=26)$ & $32.9 \%(n=47)$ \\
\hline Total & $100 \%(n=81)$ & $100 \%(n=62)$ & $100 \%(n=143)$ \\
\hline
\end{tabular}

\section{Design}

The study design was a matching-only pretest-posttest control group design. The classes ran on a modified block schedule, with classes meeting three days a week, including two 95-minute classes and one 45-minute class weekly. Of the six classes taught by the researcher, three classes were selected to receive traditional face-to-face instruction, while the three remaining classes received flipped instruction. The first author presented all instruction. Prior to receiving either type of instruction, all students completed an identical pre-test using Google Forms.

\section{Study Implementation}

Students in the face-to-face instruction group received content in a traditional format; the teacher delivered the necessary content while students took notes and asked questions when necessary. Students also participated in whole group reinforcement activities and were assigned homework relevant to the content. At the end of the unit, all students completed identical posttests to determine what they had learned. Students receiving flipped instruction were assigned to watch a video prior to attending class. Videos were teacher-made using Screencastify, a program that enables the user to capture whatever is on their screen and record their voice. Students were given five days to watch the video, take notes, and submit a question to the teacher. Several days were given to complete the assignment in order to accommodate students without Internet access. For these students, the instructor was available during lunch or after school if students were unable to access course content from home. The school also provided a monitored computer lab before school daily, to which all students had access. The instructor made every effort to ensure that every student had access to all course materials.

Students in the treatment group were instructed in Kirch's (2016) Watch-Summarize-Question method. With the WSQ method, students were to watch the video while taking notes, summarize the content, and then write a question or questions about the content, both to let the instructor know that they watched the video and to provide material for discussion during class. When students came to class, the instructor addressed the questions submitted to facilitate discussion and fill in any gaps in knowledge that students had. Then, students completed practice tasks that the control group completed for homework, as well as additional hands-on activities that students in the face-to-face group did not have time to complete.

At the conclusion of the unit, all participants in the flipped classroom completed the same posttest as the control group to determine what they had learned through the course of the unit. The assessment was aligned with state science standards and had content-related validity. The test questions were chosen from a reliable item bank from past assessments, created in collaboration with other teachers who had experience in the course content. 


\section{Survey Instrument}

The survey completed by students in the flipped classroom was adapted from an existing survey (Student Feedback on Flipped Classroom, n.d.) and included questions created by the researchers. The survey items consisted of three different response formats: Likert-scale items (ranging from Strongly Disagree to Strongly Agree), Yes or No items, and open response items. Questions were chosen based on their ability to determine how students felt about flipped instruction and how their feelings may have been shaped by circumstances. There were nine Likert-type questions, two binary response items, and five open-ended questions. The survey was reviewed by experts to determine validity of the content, and necessary revisions were made before it was administered.

\section{RESULTS}

The aim of data analysis was to determine the differences in posttest data due to method of instruction, gender, and aptitude. Aptitude level was determined by each student's achievement level on the unit pretest, which was made up of 18 questions total. Those who got 0-10 correct answers were identified as low ability level, 11-14 correct as middle ability, and 15-18 as high ability students. Refer to Table 1 for the distribution of students by instructional method and ability, as well as by instructional method and gender. A total of 14 students were not included in the data analysis due to having incomplete data.

A three-way analysis of variance (ANOVA) was conducted using SPSS to address the study's research questions. The first research question asked if there were mean differences in achievement between students experiencing flipped instruction $\left(M_{1}=14.2\right)$ and students experiencing face-to-face instruction $\left(M_{2}=14.2\right)$. When the data were analyzed, there was no difference in the means of the two groups on the posttest $F(1,124)=.000, p>.05$. Both instructional groups had equal posttest mean scores, and the estimated marginal means of both groups were equal. The second research question asked whether there was an interaction between instructional method and gender. While slight differences were observed, with females faring slightly better than males in the flipped classroom, there was no statistically significant interaction between the two variables $F(1,124)=1.443, p>.05$. Though not significant, the interaction suggests females did slightly better with the flipped class than males. Both genders performed about the same in the face-to-face class.

The third research question sought to determine if there was an interaction between instructional method and ability level. The interaction was not significant at the .05 level of significance $F(1,124)=2.589, p=.085$, implying that not one ability group did significantly better with one method of instruction over the other. However, low ability level students tended to fare slightly better with flipped instruction. The high and middle ability groups tended to perform slightly better with the face-to-face class.

\section{Survey Results}

The final research question sought to determine how students felt about their experience in the flipped classroom. At the conclusion of the unit, students in the flipped group completed a survey about their experiences with the flipped classroom. The survey consisted of nine Likerttype questions with five possible responses ranging from Strongly Disagree to Strongly Agree. In addition, there were a couple of binary response items, and five open-ended questions.

Likert response survey items. For the Likert scale statements, the top two responses (Agree and Strongly Agree) were combined to get the percent of students who rated the item with a 
favorable response. Figure 1 displays the percentages of affirmative responses. For all items, a majority of students agreed that they benefited from the flipped classroom. The only statement to which less than a majority of students responded positively was on whether the flipped classroom allowed for adequate interaction with the teacher, where $47 \%$ agreed with the statement. The two statements that students agreed with the most were: The flipped classroom allows for more time to do labs and hands on activities (77\%), and the flipped classroom gave me more time to practice what we learned (76\%). In terms of motivation to learn, $55.3 \%$ of students reported being more motivated to learn in a flipped classroom.

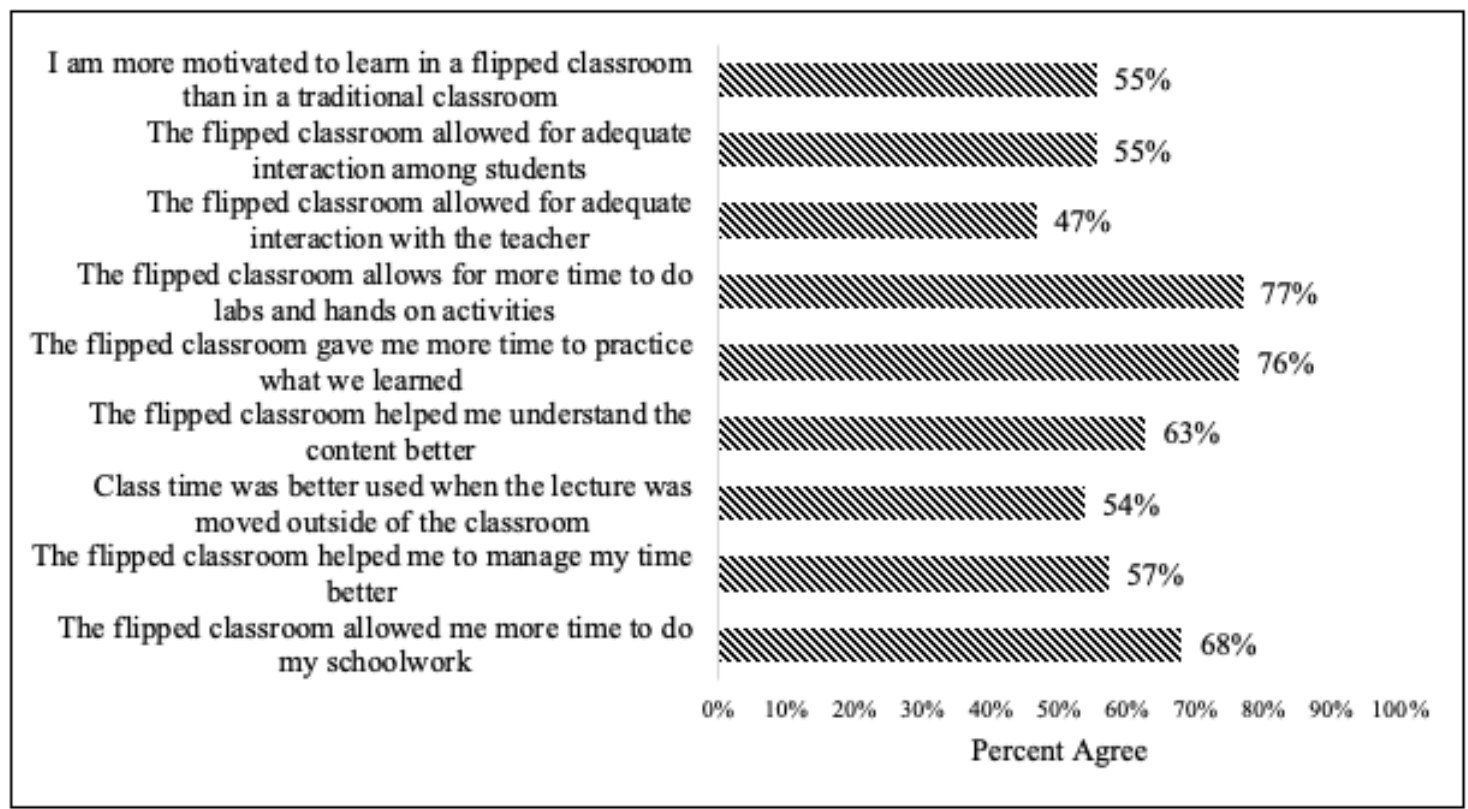

Figure 1. Percent of student agreement on Likert scale survey items

Binary response survey items. Two Yes/No questions were included on the survey. The first one asked the students whether they felt they had sufficient opportunity to ask questions for further clarification, and $91 \%(n=51)$ responded affirmatively. Of the 55 who responded to the second question, 95\% $(n=52)$ indicated that the hands-on activities during class increased their understanding of the content that was taught.

Open-ended survey items. Students were asked what they liked most about the video lectures. The most common reported response was that they enjoyed the self-paced aspect of the flipped classroom, with $29 \%$ of students reporting this as an advantage of flipped instruction. One student reported that they liked how "...in a face-to-face lecture, I might miss... something the teacher said. However, with a video, I can replay and rewind as many times as I need."

About one fifth (18\%) of students liked having access to lectures at all times, rather than just being expected to remember what was delivered during the lecture in class. About $14 \%$ of students responding stated that they felt that they had a better understanding of the content in the flipped classroom than with face-to-face instruction.

The next open-ended question asked, "What did you like least about the flipped classroom?" About a third (30\%) of the students stated that they liked this instructional model as it was and did not list anything that they would change. The most common aspect that students disliked about the flipped classroom was captured in one student's words who said, "it felt like homework." Three students reported disliking having to wait for a response to questions. 
Similarly, one student proposed the inclusion of a discussion board because, "The discussion board would allow more interaction with students from home."

In the final question, students were asked to add any comments that were not addressed previously. The majority of students expressed satisfaction with flipped learning. Overall, student feedback was very positive. The vast majority of students preferred flipped instruction to face-to-face instruction.

\section{DISCUSSION OF RESULTS AND CONCLUSIONS}

The flipped model of instruction was championed by Bergmann and Sams (2012), two high school chemistry teachers who sought to help more of their students by moving instruction outside of the classroom. While the literature on flipped learning continues to grow, most of it is being conducted at the college level (Pulham \& Mohammad, 2018). This study fills a gap in the literature by focusing on flipped learning at the middle school level.

In this quasi-experimental study of flipped learning, we found no significant differences in achievement between instructional methods, and no significant interactions with gender and ability level. It is thus reasonable to conclude that flipped instruction is at least as effective as face-to-face instruction. This equivalence in achievement agrees with the majority of the literature (Clark, 2015; Desantis et al., 2015; Gross et al., 2015; Newman et al., 2016; Ryan \& Reid, 2015).

According to Hunley (2016), it is essential that students have a positive perception of their own learning. One of the key findings of the current study is that a majority of students in the flipped classroom indicated that they benefited from the teaching model. This is also consistent with the findings of Sajid et al. (2016), who, in a study to investigate performance and students' perceptions of flipped instruction, found that students perceived the model to be beneficial but this did not translate into improved performance.

The student survey data were largely positive, with the majority of students indicating that they enjoyed the flipped model. Large percentages also felt that they learned more and were more motivated to learn. Again, this is consonant with much of the surveyed literature (Blair, Marahaj, \& Primus, 2015; Clark, 2015; Newman et al., 2016; Ryan \& Reid, 2015). Though the students disclosed that they preferred to flipped classroom, less than half of the students (47\%) agreed that the flipped classroom gave them more interaction with the teacher. This is in line with the findings presented by Clark (2015) when she introduced a flipped classroom model for her course. She noted that students were resistant at the beginning of the implementation; however, over the course of the semester, students gradually bought-in to the use of the model.

Future researchers may want to consider conducting similar studies over longer periods of time. This study was conducted over three weeks, so the novelty effect could be in place due to the short period of implementation. Extending the study to an entire semester or an entire school year would help reduce the novelty of the instructional method.

\section{RECOMMENDATIONS}

One noteworthy finding was that achievement data were equivalent across groups, which implies that it should not matter which method teachers implement if they only care about achievement. However, student engagement is an important element that should not be ignored when contemplating which method to implement, as teachers should always be using strategies that keep students engaged and motivated. On the survey, students reported 
increased engagement and motivation under the flipped model, indicating that flipped instruction could have been the lever for the change. This research, along with existing literature, provides supporting data that will help teachers make informed decisions about their instructional methods, and ultimately be able to better meet the needs of their students, whether it is with face-to-face or flipped instruction.

\section{REFERENCES}

Agnello, V., Pikas, B., Agnello, A. J., \& Pikas, A. (2011). Today's learner, preferences in teaching techniques. American Journal of Business Education (AJBE), 4(2), 1-10. https://doi.org/10.19030/ajbe.v4i2.3556

Alvarez, B. (2012). Flipping the classroom: Homework in class, lessons at home. Education Digest, 77(8), 18-21.

Arnold-Garza, S. (2014). The flipped classroom teaching model and its use for information literacy instruction. Communications in Information Literacy, 8(1), 7-22. https://doi.org/10.15760/comminfolit.2014.8.1.161

Bergmann, J., \& Sams, A. (2012). Flip your classroom: Reach every student in every class every day. Washington, DC: International society for technology in education.

Bergmann, J., \& Sams, A. (2015). Flipped learning for science instruction. Arlington, VA: International Society for Technology in Education.

Bhagat, K. K., Chang, C. N., \& Chang, C. Y. (2016). The Impact of the flipped classroom on mathematics concept meaning in high school. Educational Technology \& Society, 19(3), 134-142.

Blair, E., Maharaj, C., \& Primus, S. (2015). Performance and perception in the flipped classroom. Education and Information Technologies, 21(6), 1465-1482 https://doi.org/10.1007/s10639-015-9393-5

Bormann, J. (2014). Affordances of flipped learning and its effects on student engagement and achievement. Graduate Research Papers. 137. Retrieved from https://scholarworks.uni.edu/grp/137

Cavey, L., \& Mahavier, W. (2010). Seeing the potential in students' questions. The Mathematics Teacher, 104(2), 133-137. Retrieved from http://www.jstor.org/stable/20876802

Chen, S., Young, S. J., \& Hsiao, C. (2016). Exploring student perceptions, learning outcome and gender differences in a flipped mathematics course. British Journal of Educational Technology, 47(6), 1096-1112. https://doi.org/10.1111/bjet.12278

Clark, K. R. (2015). The effects of the flipped model of instruction on student engagement and performance in the secondary mathematics classroom. Journal of Educators Online, 12(1), 91-115. Retrieved from http://www.thejeo.com/Archives/Volume12Number1/Clark.pdf

Desantis, J., Van Curen, R., \& Putsch, J. (2015). Do students learn more from a flip? An exploration of the efficacy of flipped and traditional lessons. Journal of Interactive Learning Research, 26(1), 39-63.

El Miedany, Y., \& El Miny, Y. (2018). Rheumatology teaching: The art and science of medical education. Cham, Switzerland: Springer. 
Garrison, D., \& Kanuka, H. (2004). Blended learning: Uncovering its transformative potential in higher education. The Internet and Higher Education, 7(2), 95-105. https://doi.org/10.1016/j.iheduc.2004.02.001

González-Gómez, F., Guardiola, J., Rodríguez, Ó. M., \& Alonso, M. Á. (2012). Gender differences in e-learning satisfaction. Gender Differences in E-learning Satisfaction, 58(1), 283-290. https://doi.org/10.1016/j.compedu.2011.08.017

Graham, C. R., Woodfield, W., \& Harrison, J. B. (2013). A framework for institutional adoption and implementation of blended learning in higher education. Internet and Higher Education, 18, 4-14. https://doi.org/10.1016/j.iheduc

Grant, C. (2013). First inversion: a rationale for implementing the 'flipped approach' in tertiary music courses. Australian Journal of Music Education, 2013(1), 3-12. Retrieved from https://files.eric.ed.gov/fulltext/EJ1061810.pdf

Groff, J. (2013). Technology-rich innovative learning environments. OCED CERI Innovative Learning Environment project, 1-30. Retrieved from http://www.jengroff.net/pubs_files/Tech-Rich-ILEs_GROFF-FINAL.pdf

Gross, B., Hoffman, M., Marinari, M., DeSimone, K., \& Burke, P. (2015). Flipped @ SBU: Student satisfaction and the college classroom. Educational Research Quarterly, 39(2), 36-52. Retrieved from https://eric.ed.gov/?id=EJ1166718

Gross, D., Pietri, E. S., Anderson, G., Moyano-Camihort, K., \& Graham, M. J. (2015). Increased preclass preparation underlies student outcome improvement in the flipped classroom. CBE- Life Sciences Education, 14(4), 1-8. https://doi.org/10.1187/cbe.15-02-0040

Hunley, R. C. (2016). Teacher and student perceptions on high school science flipped classrooms: Educational breakthrough or media hype? (Dissertations, 3052). Retrieved from http://dc.etsu.edu/etd/3052

Jamaludin, R., \& Osman, S. Z. M. (2014). The use of a flipped classroom to enhance engagement and promote active learning. Journal of Education and Practice, 5(2), 124-131. Retrieved from http://www.iiste.org

Jony, S. (2016). Student centered instruction for interactive and effective teaching learning: Perceptions of teachers in Bangladesh. International Journal of Advanced Research in Education \& Technology (IJARET), 3(3), 172-178. Retrieved from http://ijaret.com/wpcontent/themes/felicity/issues/vol3issue3/mdsolaiman.pdf

Kim, M., Jung, E., de Siqueira, A., \& Huber, L. (2016). An investigation into effective pedagogies in a flipped classroom: A case study. International Journal of E-Learning \& Distance Education, 32(2), 1-15. https://doi.org/10.22458/urj.v9i2.1900

King, J. R., Biggs, S., \& Lipsky, S. (1984). Students self-questioning and summarizing as reading study strategies. Journal of Reading Behavior, 16(3), 205-218. https://doi.org/10.1080/10862968409547516

Kirch, C. (2016). Flipping with Kirch: The ups and downs from inside my flipped classroom. New Berlin, WI: The Bretzmann Group.

Lax, N., Morris, J., \& Kolber, B. J. (2016). A partial flip classroom exercise in a large introductory general biology course increases performance at multiple levels. Journal of Biological Education, 51(4), 412-426. https://doi.org/10.1080/00219266.2016.1257503 
Lee, Y. H., \& Kim, K. J. (2018). Enhancement of student perceptions of learner-centeredness and community of inquiry in flipped classrooms. BMC Medical Education, 18(1), 242. https://doi.org/10.1186/s12909-018-1347-3

Lenhart, A. (2015). A majority of American teens report access to a computer, game console, smartphone and a tablet. Retrieved on March 27, 2018, from http://www.pewinternet.org/2015/04/09/a-majority-of-american-teens-report-accessto-a-computer-game-console-smartphone-and-a-tablet/

Newman, G., Kim, J.-H., Lee, R. J., Brown, B. A., \& Huston, S. (2016). The perceived effects of flipped teaching on knowledge acquisition. The Journal of Effective Teaching, 16(1), 5271. Retrieved from http://files.eric.ed.gov/fulltext/EJ1092703.pdf

Noonoo, S. (2017). Why Flipped learning is still going strong 10 years later -edsurge news. Retrieved on March 17, 2018, from https://www.edsurge.com/news/2017-10-03-whyflipped-learning-is-still-going-strong-10-years-later

Project Tomorrow/Flipped Learning Network (2013). A second year review of flipped learning and 2013 trends in digital learning: Students' views on innovative classroom models. Irvine, CA.

Pulham, E., \& Mohammed, S. (2018). Publish or (the field will) perish: Blended learning needs more peer-reviewed publications [Blog post]. Retrieved on April 02, 2018, from https://www.brookings.edu/blog/brown-center-chalkboard/2018/01/29/publish

Ryan, M. D., \& Reid, S. A. (2015). Impact of the flipped classroom on student performance and retention: A parallel controlled study in general chemistry. Journal of Chemical Education, 93(1), 13-23. https://doi.org/10.1021/acs.jchemed.5b00717

Sajid, M. R., Laheji, A. F., Abothenain, F., Salam, Y., AlJayar, D., \& Obeidat, A. (2016). Can blended learning and the flipped classroom improve student learning and satisfaction in Saudi Arabia? International journal of medical education, 7, 281-285.

Schmidt, S. M., \& Ralph, D. L. (2016). The flipped classroom: A twist on teaching. Contemporary Issues in Education Research (CIER), 9(1), 1-6. https://doi.org/10.19030/cier.v9i1.9544

Smallhorn, M. (2017). The flipped classroom: A learning model to increase student engagement not academic achievement. Student Success, 8(2), 43-53. https://doi.org/10.5204/ssj.v8i2.381

Strayer, J. F. (2012). How learning in an inverted classroom influences cooperation, innovation and task orientation. Learning Environments Research, 15(2), 171-193. https://doi.org/10.1007/s10984-012-9108-4

Strohmyer, D. (2016). Student perceptions of flipped learning in a high school math classroom. (Doctoral dissertation). Retrieved from http://scholarworks.waldenu.edu/dissertations

Student Feedback on Flipped Classroom. (n.d.). Retrieved on April 08, 2018, from https://www.surveymonkey.com/r/X9HYF5W

Tawfik, A. A., \& Lilly, C. (2015). Using a flipped classroom approach to support problem-based learning. Technology, Knowledge and Learning, 20(3), 299-315. https://doi.org/10.1007/s10758-015-9262-8 
Wenzler, H. R. (2017). The flipped classroom model and academic achievement: a pre and posttest comparison groups study (Doctoral dissertation). Available from ProQuest Dissertations and Theses database. (UMI 10289567)

Wilson, S. G. (2013). The flipped class: A method to address the challenges of an undergraduate statistics course. Teaching of Psychology, 40(3), 193-199. https://doi.org/10.1177/0098628313487461

Correspondence: George Chitiyo, Tennessee Tech University, TN, USA.

E-mail: gchitiyo@tntech.edu 